\title{
Influence of TiN High-tensile Stress Coating on Magnetic Properties in Grain oriented Electrical Steel.
}

\author{
Y. Shingaki and S. Okabe \\ Steel Research Laboratory, JFE Steel Corporation, Kawasakidori 1, Mizushima, Kurashiki 712-8511, Japan
}

\begin{abstract}
The influence of crystal orientation on the magnetic properties of $3 \% \mathrm{Si}-\mathrm{Fe}$ single crystals was investigated by measuring iron losses and observing magnetic domain patterns in TiN-coated and chemically polished specimens. The iron loss was reduced in a TiN-coated sample whose $B$ angle was less than 4 degrees and increased in a sample whose $B$ angle was larger than 4 degrees. The improvement in the iron loss was due to a decrease in eddy current loss that corresponded to a decrease in the magnetic domain width caused by the tensile stress effect of the TiN coating. In the sample whose 8 angle was larger than 4 degrees, the eddy current loss did not change due to the TiN coating because the magnetic domain width was almost the same under alternate magnetization. Additionally, hysteresis loss increased because of increase magnetic coercive force.
\end{abstract}

Key words: grain oriented electrical steel, iron loss, tensile stress, TiN coating, $\beta$ angle, magnetic coercive force

\section{方向性電磁鋼板の磁気特性におよぼす TiN 高張力被膜の影響}

\author{
新垣之啓・岡部誠司 \\ JFE スチール株式会社スチール研究所，倉敷市水島川崎通り 1丁目（テ712-8511）
}

\section{1. はじめに}

方向性電磁鋼板は鉄の磁化容易軸 $<001>$ と鋼板の圧延方向がほ ぼ平行となるよう制御された軟磁生材料である. 主な用途として, 変圧器の鉄心に用いられている. 近年では省エネ法の改正により, 変圧器に対し, 従来の JIS 標準品に比べて基淮負荷率における全損 失を約 30\%程度低減した, いわゆるトップランナー方式が適用さ れている ${ }^{1)}$. 実際ここれらの変圧器では, 従来主流の方向性電磁鋼 板35G130（JISC2553）に比へ，板厚の低減や磁区制御技術の適用 により，鉄損を 30\%以上改善した23R085（JISC2553）などが利用 されてきている.

省エネ法改正後も，省エネルギ一化に対する意識の高まりを受 け，電磁鋼板に対しても低鉄損化の要求が高まっている.

電磁鋼板板鉄損は履歴損と渦電流損の 2 つに大別され，それぞ れに効果的な鉄損低減技術が提案されている．例えば，方向性電 磁鋼板の特徵的な結晶方位であるゴス方位（\{110\}<001>）の高度 集積化は履歴損を低減する技術であり，鋼板の電気抵抗を高める 高 $\mathrm{Si}$ 化，あるいは鋼板の板厚を低減する技術は，渦電流損の低减 に効果的である.

他にも渦電流損の低减については，これまで多くの研究がなさ れ, 磁区の動的挙動と損失との関係が明らかにされている ${ }^{2}$. 鋼板 への張力の付与も, 磁区制御を介した渦電流損低減技術の一つで

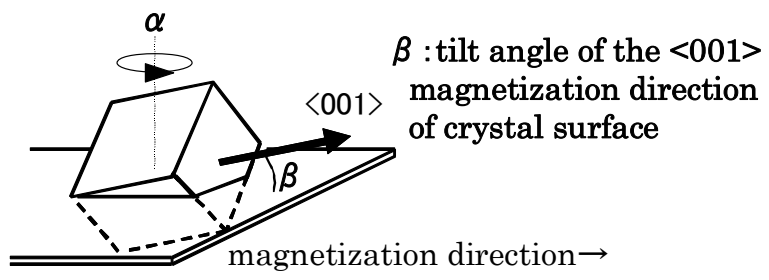

Fig. 1 Definition of $\beta$ angle in Goss orientation $(\{110\}<001>)$ crystal.
ある. この張力による鉄損低減効果は, 結晶方位, 特に $<001>$ と鋼 板面のな寸傾角（以下 $\beta$ 角とする : Fig.1）との間に特徵的な関係 を示すことが知られている3 ${ }^{3)}$.

方向性電磁鋼板では張力による鉄損低減効果を得るために, 絶 縁被膜を高温で形成し, 絶縁被膜と鋼板の熱膨張率の違いを利用 して鋼板に張力を付与している.

このような背景から,より高い張力を鋼板に印加することが可能 となる絶縁被膜に関する研究も進められており, 近年 TiN を工業 的に鋼板上に形成する技術が開発され，その鉄損改善効果が報告 されている ${ }^{4,5}$. TiN 被膜による鉄損改善効果は, 成膜前の鋼板の B8（磁化力 $800 \mathrm{~A} / \mathrm{m}$ における磁束密度 $; \mathrm{T}$ ）によって効果が異なる ことが報告されているが ${ }^{4}$, 結晶方位 ( $\beta$ 角) との関係で整理され た報告はなされていない．

そこで本研究では，ゴス方位 $(\{110\}<001>)$ 近傍の単結晶試料 に TiN 被膜を形成し，その結晶方位（ $\beta$ 角）と鉄損特性の関係に ついて調査を行った.

\section{2. 実験方法}

本実験では， $\{110\}<001>$ 方位近傍の $3 \% \mathrm{Si}-\mathrm{Fe}$ 単結晶を供試材と して用いた．試料は二次再結晶法により作製した． $3 \% \mathrm{Si}$ 鋼を $0.23 \mathrm{~mm}$ まで泠間圧延し, 一次再結晶をさせた後, 二次再結晶焼鈍 を行った. 結晶粒径は $100 \mathrm{~mm}$ 以上となるまで粗大化させた. 得ら れた二次再結晶粒は X 線回折により結晶方位を特定した後, 試料 長手方向（磁化方向）が<001>と平行となるように切り出し， $\beta$ 角 $0.4^{\circ} \sim 5.5^{\circ}$ の試料を得た.

張力による鉄損改善効果は, 鋼板表面を平滑化することで，さ らに向上するのため, 単結晶試料は化学研磨により、鏡面とした. 化学研磨後の板厚は $0.20 \mathrm{~mm}$ であった.

得られた試料は単板磁気測定装置を用い, 周波数 $50 \mathrm{~Hz}$, 最大磁束密度 $1.7 \mathrm{~T}$ で正弦励磁した際の鉄損（W17/50）と, 
履歴損として周波数 $0.1 \mathrm{~Hz}$, 最大磁束密度 $1.7 \mathrm{~T}$ での鉄損を 測定した. 渦電流損については, 交流励磁での鉄損值から 履歴損の值を減算することで求めた。 また $\beta=0.4^{\circ}, 1.6^{\circ}$ の試料に対しては<001>方向に機械的に一方向の張力を印 加した条件での鉄損測定も行なった.

測定を行なった試料の内, 比較的結晶方位の近い試料に ついては選別し， $\beta$ 角の異なる新たな試料を追加した後,

熱 CVD（Chemical Vapor Deposition）法を用いて膜厚 $1.5 \mu \mathrm{m}$ の TiN 被膜を鋼板の表裏面に成膜した ${ }^{5}$. TiN 被膜成膜後, 試料の鉄損を測定した。 また, TiN 被膜の成膜前後で消磁 を行なった後の磁区構造, および $50 \mathrm{~Hz}$, 約 $50 \mathrm{~A} / \mathrm{m}$ の交流励 磁状態での磁区構造を電子顕微鏡（加速電圧 $100 \mathrm{kV}$, 二次電 子像）によって観察した. 消磁は $800^{\circ} \mathrm{C}$ 以まで加熱した 後, 室温まで $100^{\circ} \mathrm{C} / \mathrm{Hr}$ 程度で放冷して行なった。

\section{3. 実験結果}

\section{3. $1 \mathrm{TiN}$ 被膜による張力}

被膜が鋼板に与える張力 $\sigma$ は下記の計算式で見積もることがで きるフ.

$\sigma=2 E_{\mathrm{S}} \cdot t_{\mathrm{S}} / t_{\mathrm{M}}\left(\alpha_{\mathrm{M}}-\alpha_{\mathrm{S}}\right)\left(T_{1}-T_{0}\right)$.

$E_{\mathrm{S}}$ は被膜のヤング率, $t_{\mathrm{S}}$ は被膜の厚さ, $t_{\mathrm{M}}$ は鋼板の厚さ, $\alpha_{\mathrm{M}}$ は鋼板の熱膨長係数, $\alpha_{\mathrm{S}}$ は被膜の熱膨長係数, $T_{1}$ は被膜形成温. 度, $T_{0}$ は室温である. 膜厚 $1.5 \mu \mathrm{m}$ の TiN 被膜は, 概ね2 $20 \sim 25 \mathrm{MPa}$ の張力と見積もることができる.

また $\beta=0.4^{\circ} ， 1.6^{\circ}$ の試料に対して，<001>と平行に張力を印 加しながら鉄損測定を行なった結果と TiN 被膜成膜後の鉄損の比 較をFig.2に示した. $2 つ の$ 試料のTiN被膜成膜条件は同一であり, TiN 被膜が鋼板に与える張力は同じと考えられる.

$<001>$ と平行に張力を印加した場合, $\beta=0.4^{\circ}$ て鉄損は $15 \mathrm{MPa}$ まで直線的に改善したが， $\beta=1.6^{\circ}$ では $15 \mathrm{MPa}$ でほぼ飽和した。 一方, TiN 被膜成膜後の鉄損は, $<001>$ 方向 $15 \mathrm{MPa}$ の張力を印 加して得られた鉄損に比べ, 同等ないしはさらに低い值を示した. このことから, TiN 被膜の鉄損改善効果は一方向張力換算で $15 \mathrm{MPa}$ 相当以上であることが確認できた.

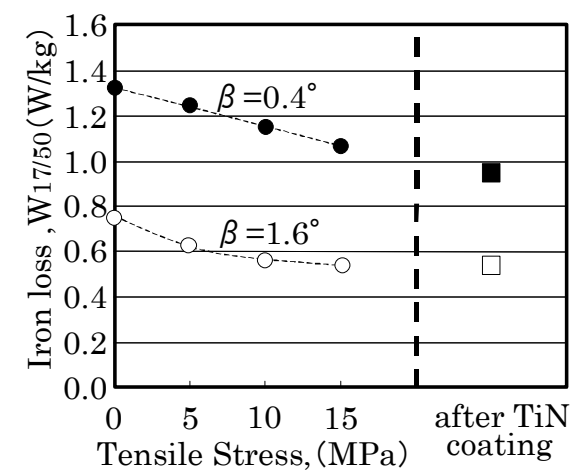

Fig. 2 Effects of tensile stress and TiN coating stress on iron loss of chemically polished $3 \% \mathrm{Si}-\mathrm{Fe}$ single crystals.

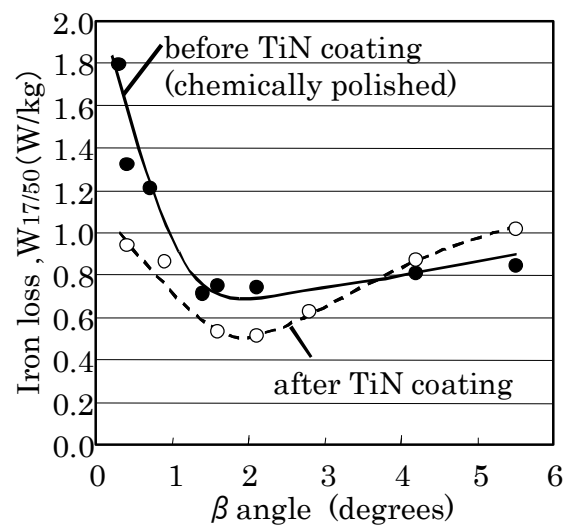

Fig. 3 Relationship between misorientation angle $\beta$ and iron loss in specimens before and after TiN coating.

(a)

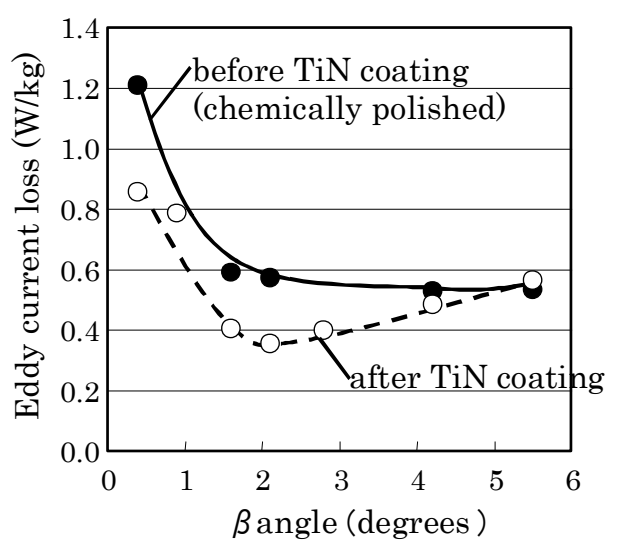

(b)

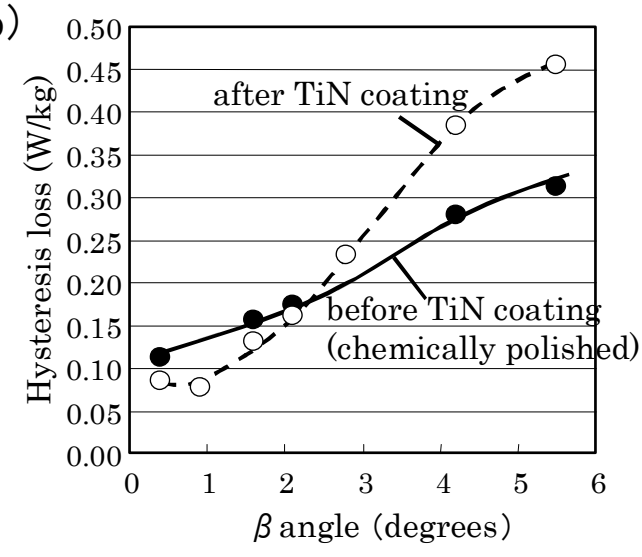

Fig. 4 Relationship between misorientation angle $\beta$ and (a) eddy current loss and (b) hysteresis loss in specimens before and after TiN coating.

\section{2 T iN 被膜張力による鉄損改善効果の結晶方位依存性}

TiN 被膜成膜前後の鉄損特性を Fig.3 に示す.

$\beta \leqq 4^{\circ}$ の試料では, $\mathrm{TiN}$ 被膜の成膜により鉄損は低減し，特に $\beta \leqq 3^{\circ}$ で，鉄損低減効果は大きかった. $\beta \fallingdotseq 2^{\circ}$ で最も低い 鉄損 $(\mathrm{W} 17 / 50=0.51 \mathrm{~W} / \mathrm{kg})$ が得られた. 一方, $\beta>4^{\circ}$ では TiN 被膜成 膜前に比べ, 成膜後, 鉄損が増加する傾向が認められた.

この結果は, $\beta \leqq 6^{\circ}$ の単結晶に対し， $<001>$ 方向に機械的に張 力 $(\sigma \fallingdotseq 15 \mathrm{MPa})$ を付与した場合, 全 $\beta$ 角範囲て鉄損が改善する 


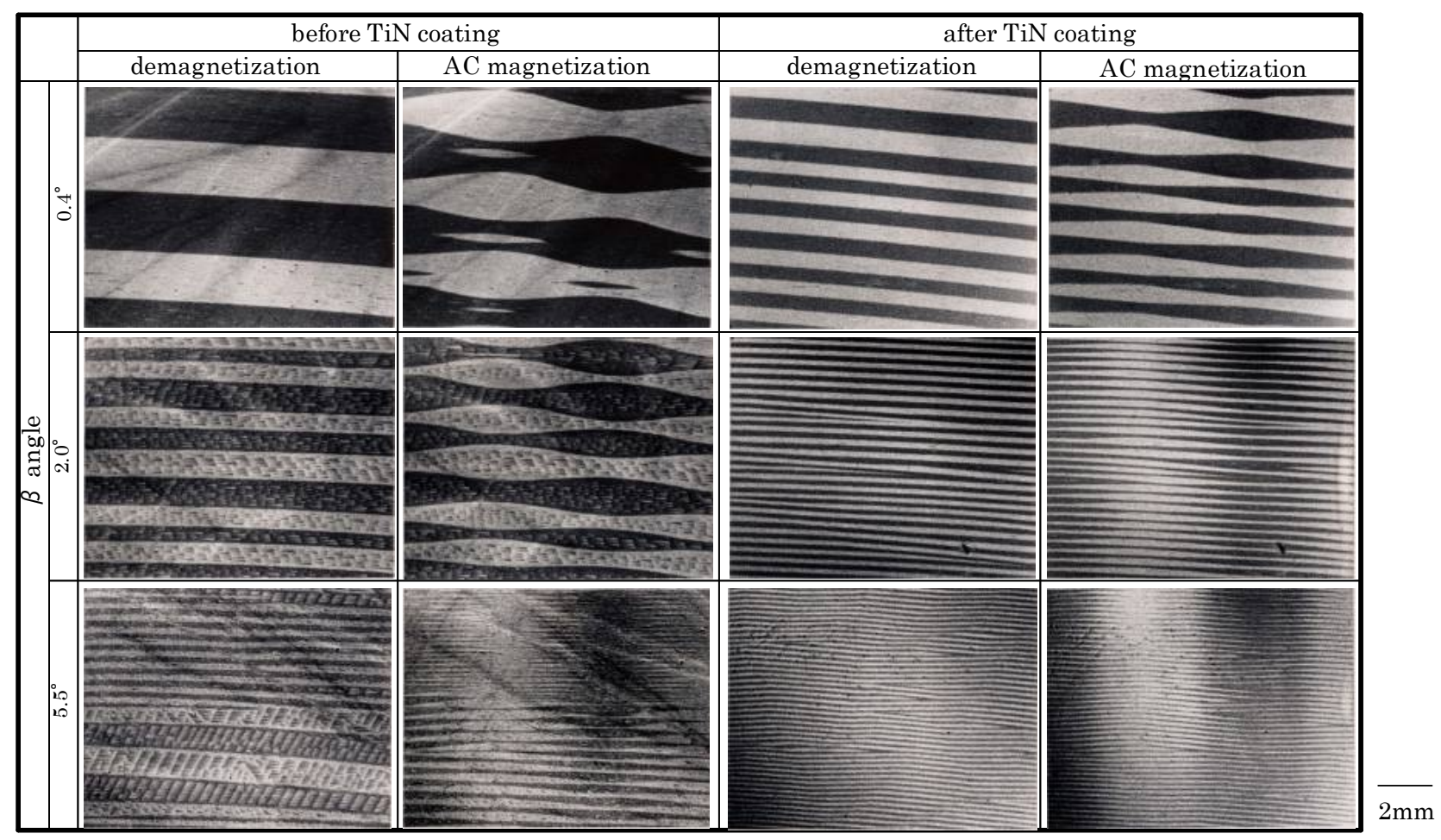

Fig. 5 Magnetic domain patterns of 3\%Si-Fe single crystals before and after TiN coating observed by 100-kV SEM.

報告例 ${ }^{3)}$ とは異なっている.

代表的な $\beta$ 角の試料について，鉄損を渦電流損と履歴損に分離 した. Fig.4 (a) に渦電流損, (b) に履歴損の結果を示す.

TiN 被膜の成膜により, $\beta \leqq 4^{\circ}$ の範囲で渦電流損の大幅な低減 が認められた. しかし $\beta>4^{\circ}$ の範囲ではほとんど変化が認められ なかった. また履歴損は, $\beta \leqq 2^{\circ}$ で低减したが， $\beta>3^{\circ}$, 特に $4^{\circ}$ 以上では増大した。

\section{3 磁区観察結果}

$\mathrm{TiN}$ 被膜成膜前後の消磁後および，周波数 $50 \mathrm{~Hz}$ ，約 $50 \mathrm{~A} / \mathrm{m}$ て励 磁した状態の磁区観察結果を Fig.5 に示す. 励磁電流は, いずれの $\beta$ 角でも磁壁の振幅が磁区幅以下となるよう設定した.

いずれの試料についても，方向性電磁鋼板に見られる典型的な ストライプ状の磁区が観察され，TiN 被膜成膜前で $\beta$ が $2.0^{\circ}$ 以上 の試料では，ランセットと呼ばれる三角形の補助磁区が多数観察 された. 特に TiN 被膜成膜前 $\beta=5.5^{\circ}$ 試料では, 磁区幅の広い領 域 (写真の下部) と狭い領域 (同上部) があり, 磁区幅の広、領 域ではランセットが櫛状に連なる磁区構造（ランセットコウム） が形成されていた。

TiN 被膜成膜前後の消磁状態の磁区構造を比較すると, 全ての $\beta$ 角で磁区幅が低減していた. 交流励磁状態での磁区幅を観察像か ら読み取ったものを Fig.6に示した. 磁区幅は必ずしも一定ではな

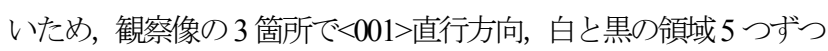
の総長さを測定し，その平均值として読夕取った．交流励磁状態 でも，TiN 被膜成膜により磁区幅は低減されていたが， $\beta=5.5^{\circ}$ 試料の磁区幅が狭い領域については, TiN 被膜成膜後の磁区幅と比 べて、ほぼ同等の磁区幅となっていた。

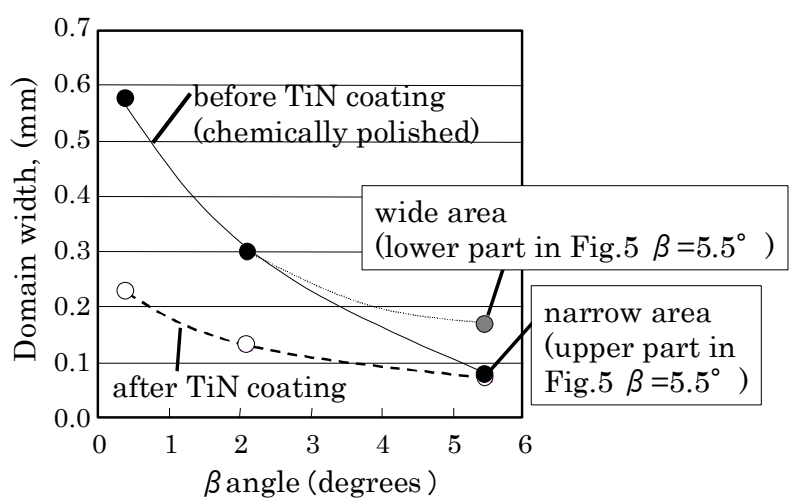

Fig. 6 Relationship between misorientation angle $\beta$ and domain width in specimens before and after TiN coating.

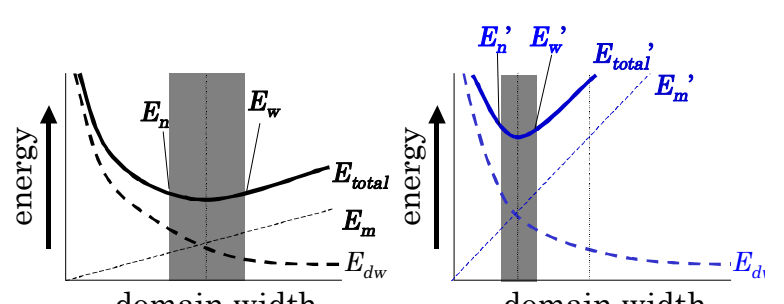

domain width

(a) low $\beta$ angle model

(b) high $\beta$ angle model

Fig. 7 Magnetic energy of specimens having low $\beta$ angle and high $\beta$ angle specimens. 


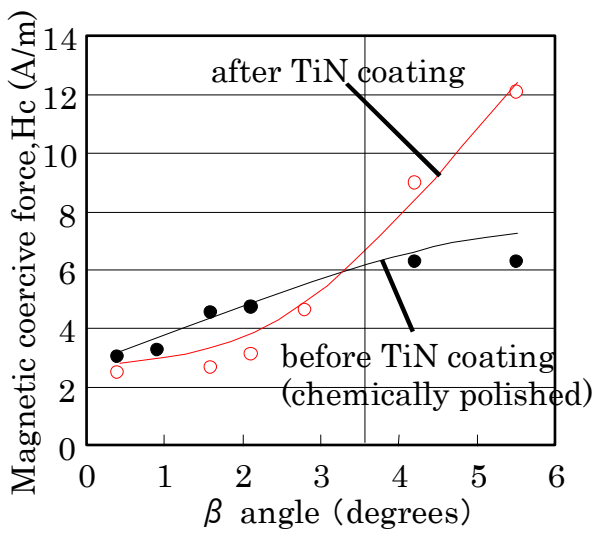

Fig. 8 Relationship between misorientation angle $\beta$ and magnetic coercive force in specimens before and after TiN coating.

\section{4. 考察}

Fig.7 に磁区幅 $d$ と磁気エネルギーの関係を示す模式図を示す. ここで $E d w$ は磁壁エネルギー，Em は静磁エネルギ一を示して いる. それぞれは磁区幅と

$E d w \propto 1 / d$.

$E m \propto(I s \sin \beta)^{2} d$.

の関係を持つことが知られている ${ }^{8}$. Is は自発磁化である. 低 $\beta$ 角領域では静磁エネルギーEm の傾きが小さいため, 磁区幅 $d$ は広 $<$, 高 $\beta$ 角領域では静磁エネルギーEm の傾きが大きいため磁区幅 $d$ は狭くなる.

ランセットに代表される補助磁区は鋼板表面の静磁エネルギー を低減し，ランセットが形成されない場合に比べて磁区幅 $d$ を広 げる効果がある. TiN 被膜成膜前 $\beta=5.5^{\circ}$ 試料の消磁状態での磁 区像では，複雑な補助磁区構造を形成することで，静磁工ネルギ 一を低減し，広い磁区幅を保っていることが分かる。

一方, 渦電流損 $W e d$ は, 磁区幅 $d$ に対して比例関係にあること が知られている9 .

Wed $\propto\left(f^{2} B m^{2} L / \rho\right) d$.

ここで $f$ は励磁周波数, $B m$ は飽和磁束密度, $L$ は板厚, $\rho$ は比 抵抗である. 張力を加えると, TiN 被膜成膜後の観察結果のように ランセット磁区は消失する. これはランセットが鋼板面垂直方向 の磁化を持っているため，鋼板面に平行な張力によって磁気弾性 エネルギーが増加し，不安定化するためである．したがって，張 力はランセットによって広く保たれていた磁区幅を低減する効果 を有している。

本研究では, TiN 被膜成膜により, 渦電流損は $\beta \leqq 4^{\circ}$ の範用で 大幅な低減が認められたが， $\beta>4^{\circ}$ ではほとんど変化が見られな かった.

Fig.5 の磁区観察結果でも $\beta \leqq 4^{\circ}$ の試料については, 消磁状態, 交流励磁状態のいずれについても, TiN 被膜成膜による磁区幅の低 減は明確であった。一方, $\beta=5.5^{\circ}$ の試料では, TiN 被膜成膜前 の試料に対し交流励磁を行なうと，消磁状態での観察結果に比べ 磁区幅は低減し, 交流励磁での磁区幅同士を比較すると, TiN 被膜 成膜前の磁区幅と TiN 被膜成膜後の磁区幅には, ほとんど差異の
ない領域が確認された. この交流励磁による磁区幅の低減は, 交 流励磁下では，ランセットコウムなどの複雑な磁区構造や多数の ランセットを形成することができないことが原因と考えられる. 当然, TiN 被膜成膜により, ランセットが完全に抑制されることで, 磁区幅は幾分低減するが，Fig.7 にも示したように，すでに磁区幅 が狭い状況では，さらに磁区幅が狭くなると急激に磁壁エネルギ 一が大きくなるため，大幅な磁区幅の変化には至らなかったと考 えられる，渦電流損を考える上では，このような交流励磁下での 磁区幅で比較すべきであり，渦電流損が低減しなかったことと， 今回の磁区観察結果はよく対応している.

履歴損測定時に得られた保磁力の測定結果を Fig.8 に示す. TiN 被膜成膜前後の履歴損の変化は, この保磁力変化に対応するもの である. この結果は, 被膜張力印加時に磁壁の移動しやすさが $\beta$ 角によって異なってくることを示唆している.

この原因については明確ではないが, TiN 被膜成膜後の磁区観察 結果から以下のように推定される.

試料は単結晶であるため, 磁化容易軸であるく001>に平行なス卜 ライプ磁区が予想されるが, 実際 TiN 被膜成膜後には, $\beta=0.4^{\circ}$ 以 外の試料では，スパイク状の先の尖った磁区が存在している.こ のスパイク状の磁区は， $\beta$ 角の大きい試料ほど頻度が高く存在し ており， $\beta=5.5^{\circ}$ の観察像は，全体として $<001>に$ 平行ではなくジ グザグ状の構造を印象づける，スパイク状の磁区は，交流励磁を 行っても同じ位置に安定して存在しており消失しないことから, このような磁区構造を作ることが，磁気エネルギ一的に有利であ ることが予想される. 例えば，スパイク状の磁区を形成し，ジグ ザグ状となることで，平行なストライプ構造より効果的に表面の 磁極同士を近づけ静磁エネルギーを下げている可能性が示唆され る. 外部から機械的に $<001>$ に平行な一方向張力を印加した場合に は，結晶磁気異方性に加えて磁気弾性エネルギーにより，ジグザ グ状の磁区は形成されにくいが，本実験で使用した TiN 被膜は面 張力であるため, 面垂直方向の磁化を持つランセットの抑制には 寄与するものの, 面内の磁区構造であるジグザグ状磁区について は影響が小さい，高 $\beta$ で形成されるジグザグ状の磁区構造では, $<001>$ に平行なストライプ磁区に比べ, 隣接する磁区との相互作用 が大きく, 磁区構造が変化しにくいことが保磁力の違いとなって 現れた可能性がある.

今後, $\beta>4^{\circ}$ に対して TiN 被膜を適用する場合には, これらの 点についても明確にする必要がある。

\section{5. まとめ}

方向性電磁鋼板に高い張力効果を有する TiN 被膜を適用 した場合の鉄損低減効果について，その結晶方位依存性を $\{110\}<001>$ 近傍の単結晶試料を用いて評価した.

膜厚 $1.5 \mu \mathrm{m}$ の TiN 被膜を付与することにより， $\beta \leqq 1.6^{\circ}$ の試料に対しては， $<001>$ 方向の一方向張力 $15 \mathrm{MPa}$ 以上に 相当する鉄損低減効果が得られた. TiN 被膜付与は $\beta \leqq 4^{\circ}$ に対して，鉄損低減効果を示すことが明らかとなった。一 方で， $\beta>4^{\circ}$ では鉄損の増大が確認された。 $\beta \leqq 4^{\circ}$ の鉄 損の改善は渦電流損によるものであり, $\beta>4^{\circ}$ の鉄損の劣 化は履歴損によるものであった. 
渦電流損の変化は, 交流励磁条件下での磁区観察結果と よく対応しており, 渦電流損の低減が顕著な $\beta$ 角範囲では磁 区幅の低減が認められ，渦電流損の変化が少ない $\beta$ 角範囲 では磁区幅の変化も小さかった. 履歴損の変化については, 保磁力の変化と対応しており, TiN 被膜付与時の磁壁移動のしや すさが $\beta$ 角によって異なる可能性が示唆された.

\section{References}

1) Y. Okazaki, et al: Denkigakkai Gijutsuhoukoku (in Japanese), vol.921, 16 (2003).

2) M. Imamura, T. Sasaki, and T. Yamaguchi: IEEE Trans. Magn., 20, 2120 (1984).

3) T. Nozawa, T. Yamamoto, Y. Matsuo and Y. Ohya: IEEE Trans. Magn., 14, 252 (1978).

4) Y. Inokuchi, K. Suzuki, and Y. Kobayashi: Tetsu - to Hagané (in Japanese), Vol.80, 932 (1994).

5) H. Yamaguchi, M. Muraki, and M. Komatsubara: CAMP-ISIJ, 17,1330 (2004).

6) U. Nishiike, T. Kan and A. Honda:JK. Ohta: J. Magn. Soc. Jpn., 17, 211 (1993).

7) A. J. Moses, S. M. Regler and J. E. Thompson: Proc. IEEE., 198, 8, 1222 (1972).

8) Charles Kittel: Reviews of Modern Physics., 21, 4, 565 (1949).

9) R. H. Pry and C. P. Bean: J. Appl. Phys., 29, 532 (1958).

\section{0年10月21日受理，2011年2月15日採録}

